\title{
Transcatheter closure of ventricular septal defect using detachable steel coil
}

\author{
G S Kalra, P K Verma, S Singh, R Arora
}

\begin{abstract}
Transcatheter closure has been attempted in selected cases of ventricular septal defects using Lock clamshell device, Rashkind umbrella device, and Sideris buttoned device. A small perimembranous ventricular septal defect with aneurysm of membranous septum in a 12 year old girl was closed successfully with a detachable steel coil of $8 \mathrm{~mm}$ diameter with four loops, after failure of deployment of a Rashkind double umbrella device.

(Heart 1999;82:395-396)
\end{abstract}

Keywords: transcatheter closure; ventricular septal defect; septal aneurysm; detachable coil; congenital heart defects

There has been significant advances in the techniques of transcatheter closure of various congenital heart defects. Beginning with the closure of patent ductus arteriosus by Porstmann et $a l,{ }^{1}$ the spectrum of successful transcatheter closure has expanded to include atrial septal defects, aortopulmonary collaterals, coronary artery and arteriovenous fistulae, Blalock-Taussig shunts, and ventricular septal defects (VSD). ${ }^{2-11}$ The experience of transcatheter closure of VSD closure is somewhat limited. ${ }^{7-11}$ Most cases of VSD closure have been done with clamshell and double umbrella devices, while, in a few, the buttoned device has been used. Vessel embolisation with steel coils in patients with congenital heart disease has been well documented, especially for aortopulmonary collaterals, coronary artery fistulae, and persistent ductus arteriosus. ${ }^{3}{ }^{42-15}$ There has, however, been no report of VSD closure with a coil. We report transcatheter closure of a perimembranous VSD using a detachable coil.

GB Pant Hospital,

University of Delhi, New Delhi-110 002, India

G S Kalra

P K Verma

S Singh

$\mathrm{R}$ Arora

Correspondence to: Dr Kalra.

Accepted for publication 3 November 1998

Case report

A 12 year old girl had a history of frequent respiratory infections in early childhood. She was diagnosed with VSD, which was managed conservatively. She had recently been treated for infective endocarditis, following which she persisted with complaints of easily tiring. Routine investigations, chest radiography, and ECG were normal. Transthoracic cross sectional echocardiography showed a $3.2 \mathrm{~mm}$ perimembranous VSD with a septal aneurysm $8 \mathrm{~mm}$ away from the aortic valve. Closure with a $12 \mathrm{~mm}$ Rashkind umbrella device (USCI, Billerica, Massachusetts, USA) was planned.

Cardiac catheterisation was performed via the transfemoral route. On angiocardiography, the VSD was profiled in $70^{\circ}$ left anterior oblique view (fig 1). The size of the VSD and its distance from the aortic valve were confirmed. The defect was crossed with a $0.035^{11}$ Terumo wire (Terumo Corp, Japan) through a 7 F Judkin's right coronary catheter. The wire was guided to the superior vena cava and the catheter was pushed over the wire through the VSD. At this point the Terumo wire was removed and a $0.038,{ }^{11} 260 \mathrm{~cm}$ long hydrophilic wire with a hand curved distal tip was advanced into the superior vena cave. The wire was then snared from the right femoral vein using a $6 \mathrm{~F}$ snare. Over this wire, an $8 \mathrm{~F}$ Mullin's sheath (Cook, Bloomington, USA) was advanced into the ascending aorta. The $12 \mathrm{~mm}$ Raskhind double umbrella was loaded into the delivery pod. The delivery pod was advanced through the Mullin's sheath to the level of tricuspid valve. The umbrella was advanced out of the pod until the end of the sheath; the arms of distal umbrella were made to partially protrude in the ascending aorta. The entire sheath-umbrella assembly was withdrawn below the aortic valve and the distal umbrella was fully pushed out of the sheath. At this stage, the assembly was withdrawn until the VSD and its position was confirmed on angiography and transthoracic echocardiography.

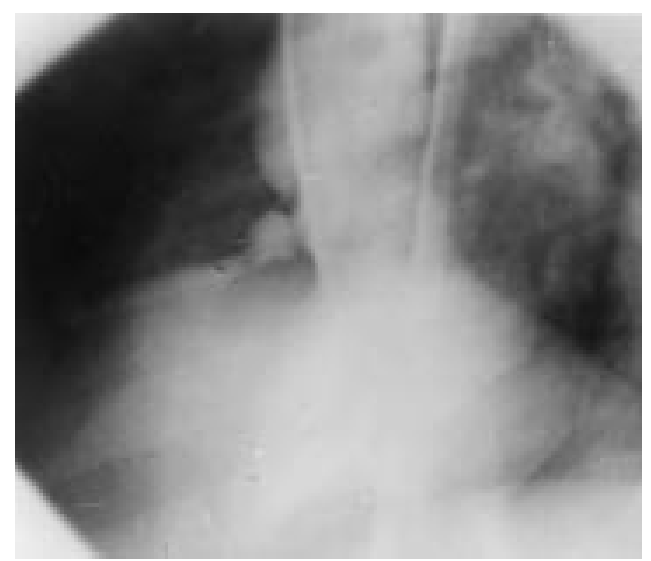

Figure 1 Left ventriculogram (left anterior oblique projection) showing a small perimembranous VSD with an aneurysm of membranous septum. 


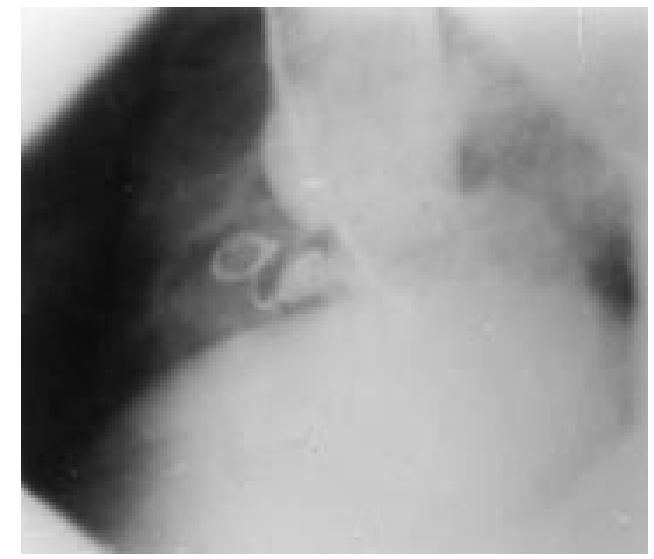

Figure 2 Left ventriculogram (left anterior oblique projection) showing a single steel coil positioned across the $V S D$, with no residual flow.

The aortic valve was carefully assessed by colour flow mapping for the presence of any aortic regurgitation. Thereafter, the umbrella was held steady and the sheath was withdrawn into the right ventricle until both sets of arms opened. While this final step was being accomplished, the entire umbrella got pulled into the right ventricle.

The VSD was recrossed and a $5 \mathrm{~F}$ multipurpose catheter (Cook) was advanced from the femoral vein into the ascending aorta. A detachable steel coil (Cook) having a helical diameter of $8 \mathrm{~mm}$ with four loops was loaded on to the delivery system by a previously described technique. ${ }^{15}$ The loaded delivery system was advanced through the multipurpose catheter. The distal two loops of the $8 \times 4$ coil were opened in the ascending aorta. The multipurpose catheter was pulled until the distal coils were positioned in the septal aneurysm on the left ventricular side of the VSD. Left ventriculography was done to confirm the position of the coil. Thereafter, the proximal coil was opened on the right ventricular side of the VSD. The coil was released after angiographic and echocardiographic confirmation of its position and absence of residual flow (fig 2). After 24 hours, repeat transthoracic and transoesophageal echocardiography revealed stable position of the coil and absence of interventricular flow. At follow up 15 months later the patient was asymptomatic and murmur free.

\section{Discussion}

Ventricular septal defect closure has been described in muscular, large perimembranous, postoperative residual, and postinfarction defects. ${ }^{7-11}$ The devices used for transcatheter closure of VSD include the Lock clamshell, Rashkind double umbrella, and Sideris buttoned device. The index case was one of the 30 cases of VSD who had transcatheter closure with a Rashkind umbrella device. All patients had septal tissue of 6 or $8 \mathrm{~mm}$ between the aortic valve and VSD for closure with a $12 \mathrm{~mm}$ or $17 \mathrm{~mm}$ umbrella, respectively. We excluded patients with poor alignment of the outlet septum, inlet defects, aortic valve prolapse, or aortic regurgitation. The present case was destined for elective closure of VSD with a $12 \mathrm{~mm}$ Rashkind umbrella device. The device slipped into the right ventricle during deployment. As she had a septal aneurysm similar to the ampulla of a persistent ductus arteriosus, we thought that it would accommodate and hold the distal loops of a steel coil conveniently. Only one $8 \mathrm{~mm}$ coil closed the VSD completely in this case. The deployment of coil in this patient was technically very simple. We feel that as many small perimembranous VSD have an associated septal aneurysm, ${ }^{16}$ they are amenable to transcatheter closure with single or multiple coils. Although most patients with small VSD are asymptomatic, they are prone to complications such as infective endocarditis, heart block, and aortic regurgitation. ${ }^{17}$ If transcatheter closure of small perimembranous VSD can be achieved without any significant morbidity, these ought to be closed nonsurgically.

In conclusion, selected cases of small VSD with septal aneurysm can be effectively closed with single or multiple coils. However, more experience is required to judge the safety and efficacy of this procedure.

1 Porstmann W, Wierny L, Warnke H, et al. Catheter closure of patent ductus arteriosus: 62 cases treated without thoracotomy. Radiol Clin North Am 1971;9:203-18.

2 Rao PS, Sideris EB, Housdorf G, et al. International experience with atrial septal defect occlusion by the buttoned device. Am Heart f 1994;128:1022-35.

3 Perry SB, Radtke W, Fellows KE, et al. Coil embolization to Perry SB, Radtke W, Fellows KE, et al. Coil embolization to
occlude aortopulmonary collateral vessels and shunts in occlude aortopulmonary collateral vessels and shunts in
patients with congenital heart disease. $\mathcal{F} \mathrm{Am}$ Coll Cardiol 1989;13:100-8.

4 Perry SB, Rome J, Keane JF, et al. Transcatheter closure of coronary artery fistulas. F Am Coll Cardiol 1992;20:205-9. 5 Terry PB, Barth KH, Kaufman SL, et al. Balloon embolization for treatment of pulmonary arteriovenous fistulas. $N$ Engl f Med 1980;302:1189-90.

6 Reidy JF, Baker E, Tynan M. Transcatheter occlusion of a Blalock-Taussig shunt with a detachable balloon in a child. Br Heart f 1983;50:101-3.

7 Lock JE, Block PC, McKay RG, et al. Transcatheter closure of ventricular septal defects. Circulation 1988;78:361-8.

8 Rigby ML, Redington AN. Primary transcatheter umbrella closure of perimembranous ventricular septal defect. $\mathrm{Br}$ Heart f 1994;72:368-71.

9 O'Laughlin MP, Mullins CE. Transcatheter occlusion of ventricular septal defect. Cathet Cardiovasc Diagn 1989;17: 175-9.

10 Bridges ND, Perry SB, Keane JF, et al. Preoperative transcathter closure of congenital muscular ventricular septal defects. N Eng $\mathcal{F}$ Med 1991;324:1312-17.

1 Nykanen DG, Perry SB, Keane JF, et al. Transcatheter occlusion of ventricular septal defects: experience in 80 patients with congenital heart disease [abstract]. Circulation 1993;88:I-532.

12 Lloyd TR, Fedderly R, Mendelsohn AM, et al. Transcatheter occlusion of patent ductus arteriosus with Gianturco coils. Circulation 1993;88:1412-20.

13 Moore JW, George L, Kirkpatrick SE, et al. Percutaneous closure of the small patent ductus arteriosus using occluding spring coils. 7 Am Coll Cardiol 1994;23:759-65.

14 Hijazi ZM, Geggel RL. Results of anterograde transcatheter Hijazi ZM, Geggel RL. Results of anterograde transcatheter
closure of patent ductus arteriosus using single or multiple Gianturco coils. Am f Cardiol 1994;74:925-9.

15 Arora R, Verma PK, Trehan V, et al. Transcatheter coil occlusion of persistent ductus arteriosus using detachable steel coils: short-term results. Ind Heart f 1997;49:60-4

16 Ramaciotti C, Keren A, Silverman NH. Importance of (perimembranous) ventricular septal aneurysms in the natural history of isolated perimembranous ventricular septal defect. Am 7 Cardiol 1986;57:268-72.

17 Kidd L, Driscoll DJ, Gersony WM, et al. Second natural history study of congenital heart defects: results of treatment of patients with ventricular septal defects. Circulation 1993;87(suppl I):38-51. 